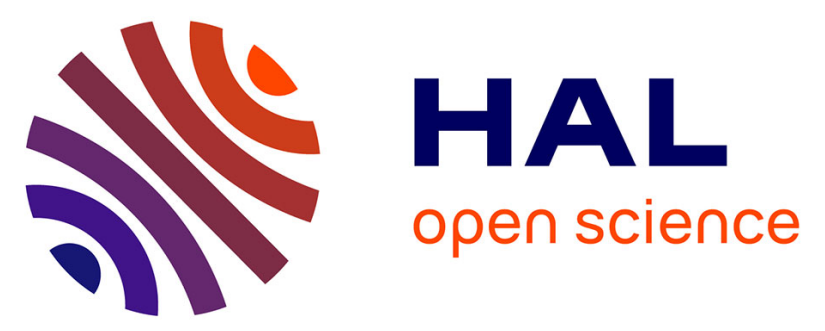

\title{
Specification, Use and Impact of the Persuasive Serious Game S'TIM in a Rehabilitation Process for Patients with Dysexecutive Syndrome
}

Julie Golliot, Michèle Timsit, Cathy Herrera, Elodie Fontugne, Alexandre Abellard, Michel Durampart

\section{To cite this version:}

Julie Golliot, Michèle Timsit, Cathy Herrera, Elodie Fontugne, Alexandre Abellard, et al.. Specification, Use and Impact of the Persuasive Serious Game S'TIM in a Rehabilitation Process for Patients with Dysexecutive Syndrome. 8th International Digital Health Conference, Apr 2018, Lyon, France. $10.1145 / 3194658.3194687$. sic_01797475

\section{HAL Id: sic 01797475 \\ https://archivesic.ccsd.cnrs.fr/sic_01797475}

Submitted on 4 Jul 2018

HAL is a multi-disciplinary open access archive for the deposit and dissemination of scientific research documents, whether they are published or not. The documents may come from teaching and research institutions in France or abroad, or from public or private research centers.
L'archive ouverte pluridisciplinaire HAL, est destinée au dépôt et à la diffusion de documents scientifiques de niveau recherche, publiés ou non, émanant des établissements d'enseignement et de recherche français ou étrangers, des laboratoires publics ou privés. 


\section{Specification, Use and Impact of the Persuasive Serious Game S'TIM in a Rehabilitation Process for Patients with Dysexecutive Syndrome}

\author{
Julie Golliot* \\ Clinique RGDS Provence-Bourbonne \\ and IMSIC, Université de Toulon \\ julie.golliot@ensc.fr \\ Elodie Fontugne \\ Clinique RGDS Provence-Bourbonne
}

\author{
Michèle Timsit \\ Clinique RGDS Provence-Bourbonne \\ m.timsit@ramsaygds.fr
}

\author{
Alexandre Abellard \\ IMSIC, Université de Toulon \\ alexandre.abellard@univ-tln.fr
}

\author{
Cathy Herrera \\ Clinique RGDS Provence-Bourbonne \\ c.herrera@ramsaygds.fr
}

\author{
Michel Durampart \\ IMSIC, Université de Toulon \\ michel.durampart@univ-tln.fr
}

\begin{abstract}
The aim of this multidisciplinary study is to specify and develop a Serious-Game (SG) to immerge patients with a dysexecutive syndrome in a virtual word. With an elaborate scenario and various challenges, the SG we named S'TIM is used on a robotised and easy-to-use touch table. The high stakes for patients are firstly to break anosognosia and intrinsically motivate patients to implicate them in their rehabilitation; Secondly to enable them to reach a sufficient metacognition level to develop their own strategy and select the most relevant in each context. Finally, to facilitate these strategies transfer in daily-life. Changes in organisations will also be observed.
\end{abstract}

\section{CCS CONCEPTS}

- Social and professional topics $\rightarrow$ Assistive technologies; People with disabilities; • Applied computing $\rightarrow$ Computerassisted instruction;

\section{KEYWORDS}

Serious-Game,Rehabilitation,Dysexecutive Syndrome,Tactile Table,Cognitive Impact,Organisational Change

\section{ACM Reference Format:}

Julie Golliot, Michèle Timsit, Cathy Herrera, Elodie Fontugne, Alexandre Abellard, and Michel Durampart. 2018. Specification, Use and Impact of the Persuasive Serious Game S'TIM in a Rehabilitation Process for Patients with Dysexecutive Syndrome. In DH'18: 2018 International Digital Health Conference, April 23-26, 2018, Lyon, France. ACM, New York, NY, USA, 2 pages. https://doi.org/10.1145/3194658.3194687

\section{INTRODUCTION}

New technologies are more and more developed and used by people of all ages. In a context of cognitive rehabilitation, most of

\footnotetext{
${ }^{*}$ Corresponding author
}

Permission to make digital or hard copies of part or all of this work for personal or classroom use is granted without fee provided that copies are not made or distributed for profit or commercial advantage and that copies bear this notice and the full citation on the first page. Copyrights for third-party components of this work must be honored.

For all other uses, contact the owner/author(s).

DH'18, April 23-26, 2018, Lyon, France

(c) 2018 Copyright held by the owner/author(s)

ACM ISBN 978-1-4503-6493-5/18/04.

https://doi.org/10.1145/3194658.3194687 the tools are traditional with activities on papers or table games. Improvements are observed but the transfer in daily-life is very limited and patients don't recover their autonomy. The ecological validity of conventional tests (with only one task mostly initiated by therapists) seems to be an issue, since they don't take care of the patients' environment. This artificial situation doesn't reproduce complexity of daily life activities and patients don't use their executive functions in order to elaborate strategies and adapt their behaviour. Ecological practices have been elaborated but they are hard to use (lack of therapists, legislation). Therefore, rehabilitation specialists are looking for a new tool to help the patients to recover their capacities and daily-life.

\section{CONTEXT}

In this $\mathrm{PhD}$ Project (preparation stage), we focus on patients with dysexecutive syndrome which can be observed after a cerebrovascular accident, a head injury with frontal lobe damage or degenerative diseases, amongst other things. Executive functions are implicated in cognitive processing requiring coordination of several sub-processes to achieve a particular goal [1] when reflex actions are insufficient. Executive troubles impair capacities of planning, strategies elaboration, updating, shifting, inhibition and attention. There are cognitive, emotional and behavioural consequences. Patients lose their autonomy and are unable to recognize their disorders (anosognosia) which limits their implication in rehabilitation.

\section{MATERIAL AND METHOD}

The aim of this research program is to specify and develop a persuasive serious-game to immerge patients in a virtual world with an elaborate scenario with various challenges.

We base our research on the self-determination theory highlight three basic needs: competence, relatedness and mostly autonomy [2]. According to this psychological theory, patient intrinsic motivation is a central element to facilitate socio-cognitive and socioaffective changes, since motivation is higher when people do not act for rewards.

The device has to be designed in order to make the most of seriousgames characteristics. Interactivity, feedbacks, playful challenges, based on rules and with a clear goal [3]. As it uses persuasive communication according to Teresa de la Hera Conde-Pumpido 


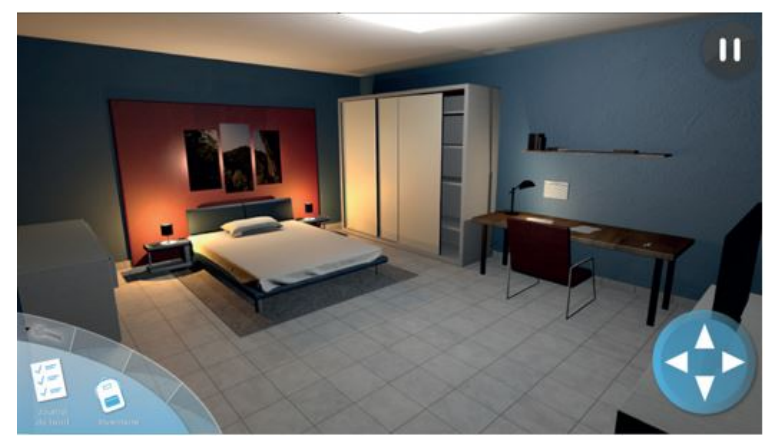

Figure 1: Screenshot of S'TIM.

model, it contains signs (haptic, sound, visual and linguistic persuasion), systems (cinematic, procedural and narrative persuasion) and context (social, affective, tactical and sensorial persuasion). Three levels are used with persuasive serious game to bring about behaviour, socio-affective and socio-cognitive changes [4]. First narration, simulation, individual adaptation and feedbacks increase patient motivation. Second, social learning by modelling and roletaking further socio-affective change. Finally, flow increases competence feelings and motivation.

In order to modify behaviours, therapists have to support patient autonomy. This engaging communication enables a self-determinate motivation. Moreover, interaction between therapists and patients around the device is crucial to favour metacognitive knowledge. Observations in a rehabilitation centre, interviews and meetings have been done for heighten months. It enabled a coordination between rehabilitation doctors, occupational therapists, neuro-psychologists, engineers and information and communication scientists. This work allowed pertinent and extensive specification of the serious-game before development on Unity 3D and clinical trials.

\section{RESULTS}

The chosen device is a robotised touch table of 46 inches which allows all degrees of movements (low-high, horizontal-vertical or any another degree). It is easy-to-use by people of all age, with or without wheelchair, sight troubles, and so on. Other applications are already used on the device and therapists haven't noticed difficulties with any patients.

Each detail of the serious-game and its use was discussed with all the experts listed above to take into account the various needs. Furthermore, this device is designed for patients and therapists ; thus, their implication since the beginning of the process reduces objections and rejections. With therapists' care, patients should be implicated, acquire pertinent strategies, be intrinsically motivated (self-determination theory), improve their self-respect, their self-efficiency and be more empathic. Collected data will enable qualitative and quantitative analyses. The serious-game development is made on Unity3D, a game development platform.

A first prototype using the main decided mechanisms has been developped. Patients and therapists' feedbacks give tools to improve the future version (Fig. 1). With therapists' care, S'TIM will transfer patients at the heart of their rehabilitation.

\section{LIMITS AND PERSPECTIVES}

This technology presents some limits. Patients could reject it or have worse results than expected if they have mental difficulties. Moreover, only some therapists were implicated in the development, so others could reject the device if the accompanying is insufficient. For patients, three stakes are expected and analyzed in clinical studies. First, to break the anosognosia and intrinsically motivate patients to implicate them in their rehabilitation. Second, to enable them to reach a sufficient metacognition level to develop their own strategy and select the most relevant in each context. Finally, to facilitate these strategies transfer in daily-life.

Standardized psychometric tests will be conducted before the study, after the two-months rehabilitation training and three months later in order to validate the serious-game pertinence (GREFEX set for cognitive evaluation, HAD scale for thymic criterion and IDSC scale for the behavior).

Therapists will keep their fundamental role. They will not have to give some background but to contextualize knowledge to favour transfer (didactic action). Patients should be more implicated, intrinsically motivated, participate more [5] and be less dependent. Standardized situations with the SG will allow the study of quantitative data and to objective changes.

Finally, articulation between goals, actor system and technic dimension will create organisational change [6]. The introduction of this technology has to be guided to avoid a situation with more disorders than solutions and optimize the device use.

\section{CONCLUSION}

This new, innovating and multidisciplinary study presents high stakes for the future of patients with dysexecutive syndrome. Theories of information and communication sciences, educational sciences, cognitive sciences, psychology and neuropsychology are implicated in the design and the use of this new technology by rehabilitation centers already established. With therapists' implication, S'TIM will increase patient autonomy and transfer them at the heart of their rehabilitation and give them a chance to go back to their daily life.

\section{REFERENCES}

[1] Olivier Godefroy and coll. 2004. Syndromes frontaux et dysexécutifs. Rev Neurol 160, 10 (October 2004), 899-909. https://doi.org/10.1016/S0035-3787(04)71071-1

[2] Richard M. Ryan and Edward L. Deci. 2002. Overview of self-determination theory: An organismic dialectal perspective. In Handbook of self-determination research. University of Rochester Press, Rochester, NY, 3-33.

[3] Julian Alvarez and Djamel Djaouti. 2012. Introduction au Serious Game (2nd. ed.). Questions Théoriques, Paris.

[4] Didier Courbet and Marie-Pierre Fourquet-Courbet. 2015. Les serious games, dispositifs de communication persuasive: quels processus socio-cognitifs et socioaffectifs dans les usages? Quels effets sur les joueurs? Etat des recherches et nouvelles perspectives. Réseaux 33, 194, 199-228.

[5] Carole Groleau and Anne Mayère. 2007. L'articulation technologies - organisations: des pistes pour une approche communicationnelle. Commun. Organ. 31 (July 2007), 140-163.

[6] Willy Barroy, Michel Durampart, and Philippe Bonfils. 2016. Les dispositifs numériques de formation: un enjeu de changements organisationnels. Proceedings of MTO, Presse des Mines, Paris. 